\title{
Gevaş ve Başkale Meslek Yüksekokulları Bitkisel ve Hayvansal Üretim Bölümü Mezunlarının İstihdam Edilme Durumlarının Değerlendirilmesi
}

\author{
Hasan ÇELÍKYÜREK ${ }^{1 *}$, Cüneyt TEMÜR ${ }^{1}$, Haydar BALCI ${ }^{2}$ \\ Mehmet Şerif SARIMURAT ${ }^{3}$
}

\author{
${ }^{1}$ Van Yüzüncü Y1l Üniversitesi, Ziraat Fakültesi, Zootekni Bölümü,65040,Van, Türkiye \\ ${ }^{2}$ Van Yüzüncü Yıl Üniversitesi, Gevaş Meslek Yüksekokulu, 65700, Gevaş/Van, Türkiye \\ ${ }^{3}$ Van Yüzüncü Yıl Üniversitesi, Başkale Meslek Yüksekokulu, 65040, Van, Türkiye
}

Hasan ÇELIKYÜREK, ORCID: 0000-0001-5154-7979, Cüneyt TEMÜR, ORCID: 0000-0001-7952-7566, Haydar BALCI, ORCID:0000-0003-0210-3639, Mehmet Șerif SARIMURAT, ORCID: 0000-0001-6695-709X

\section{MAKALE B İ L Ġ́ İ ÖZ}

Araștırma Makalesi

: 21.11 .202

Kabul : 21.12.2021

\section{Anahtar Kelimeler}

Meslek Yüksekokulları

Bitkisel ve Hayvansal

Üretim

İstihdam

\section{* Sorumlu Yazar}

hasancy@yyu.edu.tı
Son yıllarda Türkiye'de tarımsal mesleki eğitime ilgi azalmaktadır. Tarım ve buna bağlı olarak gıda sektörünün stratejik önemi dikkate alındığında bu durum önemli bir sorun olarak görülmelidir. Van Yüzüncü Yıl Üniversitesi, Gevaş ve Başkale Meslek Yüksekokulları, Bitkisel ve Hayvansal Üretim Bölümü, 2005 ile 2019 yılları arasındaki mezun öğrencilerin istihdam durumları araştırılmıştır. Araştırmada mezunların bitirdiği programa göre istihdam edilme durumu ve çalışma koşulları değerlendirilmiştir. Buna göre ankete katılan mezun öğrencilerin $\%$ 73.5'i okulu bitirdikten sonraki hedef ve beklentilerinin gerçekleşmediğini belirtmişlerdir. Mezunların \%53.9'u aldıkları eğitimin mesleği sevmelerini sağladığı beyanında bulunmuşlardır. Mezunların \%45.1'i alan dışında, \%34,3'nün çalışmadığı, \% 7.8'inin mezun olduğu alanda çalıştığ 1 ve \%12.7'sinin ise okumaya devam ettiklerini beyan etmişlerdir. Bunlara rağmen okudukları programı çevrelerine tavsiye edebileceklerin oran $1 \% 58.8$, etmeyeceklerin oran 1 ise $\% 41.2$ şeklindedir. 2017-2019 yılı mezunları diğer mezuniyet yıllarına göre daha kısa (03 ay) sürede iş buldukları tespit edilmiştir. Fakat bu mezuniyet grubunun büyük bir kısmı kimi nedenlerden dolayı hiç çalışmayan grubun çoğunluğunu oluşturmaktadır. 17-20 ve 33-36 yaş mezunlarının mezun olduktan sonra hedef ve beklentilerinin değiştiğini, 21-24, 25-28 ve 29-32 yaş grubu mezunlarının çoğunlukla hedef ve beklentilerinin değişmediğini ifade etmişlerdir. 37 ve üzeri yaş grubu mezunların hedef ve beklentilerinin kısmen değiştiğini ve çoğunlukla 12 ay ve üzeri sürelerde kendi alanlarında çalıştıklarını beyan etmişlerdir. Mezun olunan program bakımından Organik Tarım, Tarla Tarımı ve Bahçe Ziraatı programı mezunları çoğunlukla alan dışında ve kısa sürelerde çalıştıklarını ve aylık ücretlerinin düşük olduğunu bildirmişlerdir. Hayvansal Üretim program mezunlarının durumları ise kendi alanlarında, aylık ücretlerinin yüksek ve uzun süreler çalıştıklarını beyan etmişlerdir. Çalışmanın sonuçlarına göre öğrencilerin mezun olduğu program alanında istihdam edilme oranlarının çok düşük düzeyde olduğu ve sektörün taleplerini karşılamadıkları anlaşılmaktadır. Günümüzde meslek yüksekokullarından mezun öğrencilere yüklenilen misyon maalesef işlevini tam olarak yerine getirememektedir. Bunun sonucu olarak öğrencilerin bitkisel ve hayvansal üretim bölümlerine ilgileri her geçen gün azalmaktadır. 


\section{Evaluation of Employment Status of Graduates of Gevaş and Başkale Vocational Schools, Department of Plant and Animal Production}

\begin{tabular}{|c|c|}
\hline ARTICLE INFO & ABSTRACT \\
\hline $\begin{array}{l}\text { Received : 21.11.2021 } \\
\text { Accepted : 21.12.2021 }\end{array}$ & $\begin{array}{l}\text { In recent years, interest in agricultural vocational education has been decreasing in } \\
\text { Turkey. Considering the strategic importance of agriculture and accordingly the } \\
\text { food sector, this situation should be seen as an important problem. The } \\
\text { employment status of students who graduated from Van Yüzüncü Yl University, } \\
\text { Gevaş and Başkale Vocational Schools, Department of Crop and Animal } \\
\text { Production between } 2005 \text { and } 2019 \text { were investigated. In the study, employment } \\
\text { status and working conditions of graduate students were evaluated according to } \\
\text { the program they completed. Accordingly, } 73.5 \% \text { of the graduated students who }\end{array}$ \\
\hline $\begin{array}{l}\text { Keywords } \\
\text { Vocational Schools } \\
\text { Plant and Animal } \\
\text { Production } \\
\text { Employment }\end{array}$ & $\begin{array}{l}\text { participated in the survey stated that their goals and expectations after graduating } \\
\text { from school were not realized. } 53.9 \% \text { of the graduates stated that the education } \\
\text { they received made them love the profession. } 45.1 \% \text { of the graduated students } \\
\text { stated that they work outside the sector, } 34.3 \% \text { do not work, } 7.8 \% \text { work in the } \\
\text { field they graduated from, and } 12.7 \% \text { continue to study. Despite these, the rate of } \\
\text { those who can recommend the program they have read to their circle is } 58.8 \% \text { and }\end{array}$ \\
\hline $\begin{array}{l}\text { * Corresponding Author } \\
\text { hasancy@yyu.edu.tr }\end{array}$ & $\begin{array}{l}\text { the rate of those who will not is } 41.2 \% \text {. It has been determined that } 2017-2019 \\
\text { graduates found a job in a shorter time (0-3 months) compared to other graduation } \\
\text { years. However, a large part of this graduate group constitutes the majority of the } \\
\text { group that has never worked for some reason. The goals and expectations of } \\
\text { graduates aged } 17-20 \text { and } 33-36 \text { have changed after graduation, but graduates of } \\
\text { the } 21-24,25-28 \text { and } 29-32 \text { age group they mostly stated that their goals and } \\
\text { expectations have not changed. They stated that the goals and expectations of } \\
\text { graduates aged } 37 \text { and over have changed partially and that they mostly work in } \\
\text { their own sector for } 12 \text { months or more. In terms of the graduated program, } \\
\text { Organic Agriculture, Field Agriculture and Horticultural Agriculture program } \\
\text { graduates mostly work outside the sector and they reported that they work for } \\
\text { short periods of time and their monthly wages are low. On the other hand, they } \\
\text { declared that they work in their own sector for long periods of time with high } \\
\text { monthly wages. According to the results of the study, it is understood that the } \\
\text { employment rate of the students in the program area they graduated from is very } \\
\text { low and they do not meet the demands of the sector. Unfortunately, the mission } \\
\text { gave to the graduates of vocational schools today cannot fully fulfill its function. } \\
\text { As a result, students' interest in plant and animal production departments is } \\
\text { decreasing day by day. }\end{array}$ \\
\hline
\end{tabular}

\section{Giriş}

Gelişmekte olan ülkelerin kalkınma süreçlerini doğru yönetmek ve hızlandırmak, özellikle sanayi ve hizmet sektöründeki vasıflı eleman ihtiyaçlarının karşılanmasıyla mümkün olacağı bir gerçektir. Ülkemizde ara eleman yetiştirmek amacıyla açılan meslek yüksekokullarının sayısı hızla artmaktadır (İşseveroğlu ve Gençoğlu, 2011). Bu okulların açılmasındaki temel amaç öğrencilerin seçtiği mesleğin geleceklerini nasıl şekillendireceğini anlamaları, seçtiği mesleği benimsemeleri ve saygı duymalarını sağlamaktır. Bununla birlikte öğrenciler meslek seçimlerini yaşadıkları sosyal çevre, aile, sektördeki iş imkanları, bu 
sektörde çalışanların hayat standartları, orta öğretimde aldıkları eğitim ile kendi hedefleri arasındaki bağlantıyı kurup, isteyerek yada çeşitli faktörlerin etkisiyle istemeyerek seçim yapmaktadırlar (Özuğur ve ark., 2016).

Bitki, hayvan ve çevre sağlığının iyileştirilmesi ile bunların olumsuz etkilerini ortadan kaldırmak insan sağlığı ve refahı açısından da son derece önemlidir. Bunun için bitkisel ve hayvansal üretim bölümlerine gereken önem verilmeli ve bu alanlarda nitelikli insan gücü yetiştirilmeye devam edilmelidir. Eğitimin olmadığı bir ülkede üretim, üretimin olmadığı bir ülkede ise istihdam, refah, huzur ve gelişmişlikten bahsetmek zordur. Meslek yüksekokullarından mezun öğrencilerin tarım, ticaret, sanayi ve hizmet sektörlerinde ara eleman olarak istihdam edilmeleri konusundaki ilgi istenen düzeyde değildir. Ülke ekonomisinin kalkınmasında mesleğinde uzman, teknolojiye hâkim, sektör ihtiyaçlarına göre yetiştirilen ve sektörle iç içe olan bu elemanlar ülke kalkınmasında hiç şüphesiz itici bir güçtür (Çelikyürek ve ark., 2017)

Bununla birlikte mesleki eğitim veren kurumlar başarılı öğrenciler tarafından tercih edilmemektedir. Bireylerin ilgi, istek ve yetenekleriyle uyumlu olmayan bir mesleği seçmeleriyle bu meslekte başarılı olamayacakları ve istenen düzeyde bir eğitim alamayacakları aşikârdır. Bunun sonucu olarak ta eğitim kaynaklarının etkin bir şekilde kullanılamaması ve sektörlerin ihtiyaç duyduğu alanlara yönelik mesleki eğitim kurumlarının uyumsuzluğu söz konusu olmaktadır. Tarım sektörünün ilgili Meslek Yüksekokulu mezunlarından beklentileri diğer sektörlerden farklıdır. Tarımsal faaliyetler doğa koşullarına bağlıdır. Toprak, bitki ve hayvan üzerinde çalışıldığından bilinçli ve sürekli olarak iş takibi gerektirir. Üretim sürecinde, mesai kavramı gün, hafta, ay, yıl içerisinde belirli saatlerle sınırlı değildir. Tatiller iş veren ya da çalışanlar tarafından değil iş akışı ile belirlenmektedir. Üretim faaliyetlerinin her aşamasında hijyen, piyasa ve teknolojinin takip edilip gerekli güncellemelerin yapılması gerekmektedir. Dönemlere göre üretim planlaması yapılmalıdır. Geleneksel üretim bilgilerinin değerlendirilip modern üretim uygulamalarının gerçekleştirilmesi gereklidir. İletişim teknolojilerinin hedeflere uygun şekilde kullanılması, mekanizasyon uygulamalarına hakim olunması zorunludur. Problemlerin doğru şekilde tespit edilip kısa zamanda ve köklü olarak çözülmesi kaçınılmazdır. Çevre bilinci ve doğal dengenin korunması göz ardı edilmeden üretim gerçekleştirilmelidir. Bu beklentilere cevap verebilecek donanıma sahip mezun yetiştirilmediği taktirde zincirleme olarak hem kalite hem de sürdürülebilirlik açısından problemlerle karşılaşıllacaktır (Atay ve ark., 2016; Uçar ve Özerbaş, 2013; Kaya, 2014). Bu durumun en büyük göstergesi de ülkemizde son 10 y1lda olduğu gibi meslek yüksekokullarında bitkisel ve hayvansal üretim bölümü programlarına talep azalmakta, 10 öğrencinin altında kayıt yapılan programlara alım durdurulmakta ve nihayet program kapatılmaktadır. Hâlbuki tarım sektöründeki problemlerin çözüm aşamasında ilgili meslek yüksekokulları mezunlarının katkılarının sağlanması oldukça önemlidir.

Öğrencilerin bitkisel ve hayvansal üretim bölümlerinden mezun olduktan sonraki durumlarının tespiti, bu eğitim kurumlarının etkinlik ve sürdürülebilirliği hakkında bilgilerin verileceği bu çalışma, Gevaş ve Başkale Meslek Yüksekokul'ları Bitkisel ve Hayvansal Üretim bölümlerinden mezun olan öğrencilerin mezun olduktan sonraki durumlarının tespiti ve değerlendirilmesi amaciyla gerçekleştirilmiştir. 


\section{Materyal ve Metot}

Van Yüzüncü Yıl Üniversitesi, Gevaş ve Başkale Meslek Yüksekokullarının Bitkisel ve Hayvansal Üretim Bölümleri altında kapanan ve halen açık programlardan 2005-2019 yılları arasında mezun olan öğrenciler arasında yapılan çalışmada 102 mezun öğrenciye ulaşılmış ve öğrencilerden anketi cevaplamaları istenmiştir. Kapanan programlardan "Süt ve Besi Hayvancılığı", "Büyükbaş ve Küçükbaş Hayvan Yetiştiriciliği” ve "Hayvansal Üretim” programlarının öğrenci sayılarının az olması sebebi ile bu programda okuyan öğrencilerin verileri Hayvansal Üretim programı adıyla bir araya getirilmiştir. Anket Google Online Formlar platformundan faydalanılarak oluşturulmuş ve anket linki mezunlara SMS, mail, Facebook, Instagram, WhatsApp veya diğer sosyal ortamlardan ulaştırılmıştır. Bu yolla mezun öğrencilerin anket sorularını mekân zorunluluğu olmaksızın ve baskı altında kalmadan cevap vermeleri amaçlanmıştır. Çalışmada mezunların bitirdiği programa göre istihdam edilme durumu ve çalışma koşulları değerlendirilmiştir.

Çalışmada kategorik değişkenler için frekans tablosu düzenlenmiş, değişkenler arası ilşkileri belirlemek için de Ki-kare (Chi-Square) testi ile uyum analizi (Correspondance Analysis) yapılmıştır. Analizlerde SAS (2020) yazılım programı kullanılmıştır.

\section{Bulgular ve Tartışma}

\section{Frekans analizi sonuçlarına göre bulguların değerlendirilmesi;}

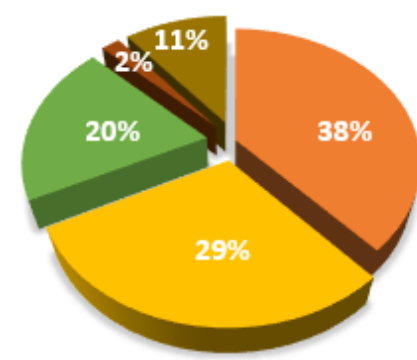

Şekil 1. Öğrencilerin mezun oldukları program.

Figure 1. The department from which the students graduated.

Mezunların yaş guruplandırmasında \%39.2 ile birinci sırayı 21-24 yaş grubu öğrencileri oluştururken, ikinci sırayı \%31.4 ile 25-28 yaş grubu öğrencileroluşturmaktadır. Daha sonra sırası ile \%15.7 ile 29-32 yaş grubu üçüncü, \%7.8 ile 37 yaş ve üzeri dördüncü, \%2.9 ile 17-20 yaş grubu ile 33-36 yaş grubu öğrencilerinin oluşturduğu tespit edilmiştir. (Şekil 2)
Mezunların \%38.2 si Organik Tarım, \%29.4'ü Bahçe Ziraatı, \%19.6's1 Laborant ve Veteriner, \%2'si Hayvansal Üretim ve \%10.8'i Tarla Tarımı programlarından mezun olanlar oluşturmuştur. (Şekil 1)

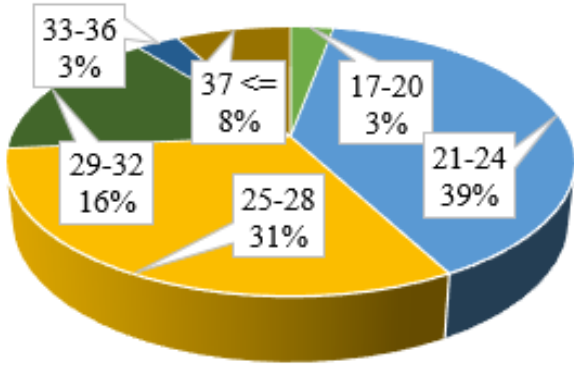

Şekil 2. Öğrencilerin yaş grupları Figure 2. Age groups of students 


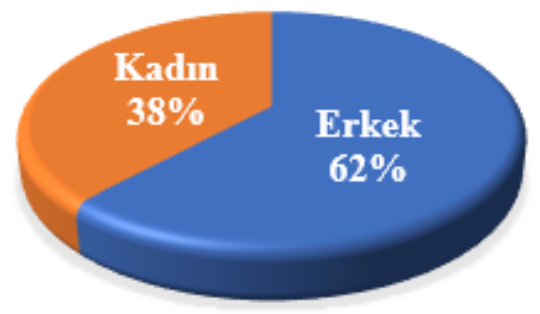

\author{
Kendilerine ulaşılan mezun \\ öğrencilerin \%61.8'i Erkek, \\ \%38.2'si kadınlardan oluşmaktadır. \\ (Şekil 3)
}

Şekil 3. Öğrencilerin cinsiyetleri Figure 3. Gender of the students

Çalışmaya katılan mezunlar ile yapılan anket sonucu elde edilen verilerden önemli görülen sonuçlar Tablo 1'de verilmiştir.

Tablo 1. Sorulara ilişkin frekans analizi

Table 1. Frequency analysis of the questions

\begin{tabular}{|c|c|c|c|c|c|}
\hline $\begin{array}{l}\text { Okulu bitirdikten sonraki hedefleriniz - } \\
\text { beklentileriniz gerçekleşti mi? }\end{array}$ & $\mathrm{n}$ & $\%$ & $\begin{array}{l}\text { Aldığınız eğitim mesleği } \\
\text { sevmenizi sağladı mı? }\end{array}$ & $\mathrm{n}$ & $\%$ \\
\hline Evet & 10 & 9.8 & Evet & 55 & 53.9 \\
\hline Hayır & 75 & 73.5 & Hayır & 21 & 20.6 \\
\hline Kismen & 17 & 16.7 & Kismen & 26 & 25.5 \\
\hline $\begin{array}{l}\text { Türkiye şartlarına göre yaşam standardınızı } \\
\text { nasıl tanımlarsınız? }\end{array}$ & & & Çalışma Durumunuz & & \\
\hline Çok düşük & 30 & 29.4 & Alanında çalışıyor & 8 & 7.8 \\
\hline Düşük & 32 & 31.4 & Alan dışında çalışıyor & 46 & 45.1 \\
\hline Orta & 36 & 35.3 & Çalışmıyor & 35 & 34.3 \\
\hline Yüksek & 4 & 3.9 & Okuyor & 13 & 12.7 \\
\hline $\begin{array}{l}\text { Mezun olduğunuz ilk dönemlerde } \\
\text { ayrıldığınız işlerden neden ayrıldınız? }\end{array}$ & & & $\begin{array}{l}\text { Mezun olduktan sonra ne kadar } \\
\text { sürede iş buldunuz }\end{array}$ & & \\
\hline Sektör dışında çalışıyordum & 18 & 17.6 & $0-3$ ay & 11 & 10.8 \\
\hline $\begin{array}{l}\text { Kariyer imkânı daha iyi olan bir işe girmek } \\
\text { için }\end{array}$ & 11 & 10.8 & $3-6$ ay & 8 & 7.8 \\
\hline Aldığım ücret yeterli olmadığından & 14 & 13.7 & $6-9$ ay & 6 & 5.9 \\
\hline $\begin{array}{l}\text { Yöneticilerim veya çalışma arkadaşlarım } \\
\text { tarafından rahatsız edildiğim icin }\end{array}$ & 6 & 5.9 & $\begin{array}{l}9-12 \text { ay } \\
12 \text { av ve üzeri }\end{array}$ & $\begin{array}{r}7 \\
15\end{array}$ & $\begin{array}{r}6.9 \\
14.7\end{array}$ \\
\hline Hiç çalışmadım & 38 & 37.3 & Çalışmıyorum & 46 & 45.1 \\
\hline Ayrılmadım, halen aynı işte çalışıyorum & 15 & 14.7 & Ailem ile birlikteyim, iş aramadım & 9 & 8.8 \\
\hline $\begin{array}{l}\text { Mezun olduktan sonra ilk girdiğiniz işlerde } \\
\text { ortalama ne kadar süreyle çalıştınız? }\end{array}$ & & & $\begin{array}{l}\text { Okuduğunuz programı çevrenize } \\
\text { tavsiye eder misiniz? }\end{array}$ & & \\
\hline $0-3$ ay & 11 & 10.8 & Evet & 60 & 58.8 \\
\hline $3-6$ ay & 7 & 6.9 & Hayır & 42 & 41.2 \\
\hline $6-9$ ay & 4 & 3.9 & Mezuniyet Yilınız & & \\
\hline $9-12$ ay & 10 & 9.8 & $2005-2007$ & 5 & 4.8 \\
\hline $12-18$ ay & 6 & 5.9 & $2008-2010$ & 12 & 11.4 \\
\hline $18-24$ ay & 4 & 3.9 & 2011-2013 & 11 & 10.5 \\
\hline 24 ay ve üzeri & 15 & 14.7 & 2014-2016 & 33 & 31.4 \\
\hline Hiç çalışmadım & 45 & 44.1 & 2017-2019 & 44 & 41.9 \\
\hline
\end{tabular}


Mezuniyet yılı bakımından ankete katılan öğrencilerin \%41.9'u 2017-2019 yılı mezunlarını, \%31.4'ü 2014-2016 yılı, \%10.5'i 2011-2013 yılı, \%11,4'ü 2008-2010 yılı ve \%4.8 ile 2005-2007 yılı mezunlarından oluşmaktadır.

Ankete katılan mezunların üniversiteyi okumak için geldikleri ilin \%92.2 oranı ile Van ili ve sırası ile Ağrı, Hakkâri, Mardin, Rize, Mersin ve İzmir oldukları tespit edilmiştir. Söz konusu öğrencilerin ankete katıldıkları süre içerisinde iş bularak çalıştıkları il olarak \%61.8 ile Van ili başta gelmektedir. Ardından \%7.8 ile Diyarbakır, \%4.9 ile Hakkâri, \%2.9 oranları ile Ağrı, Mardin, Şırnak ve İstanbul illerinde iş bulduklarını bildirmişlerdir. Yine ankete katılan öğrencilerin \%70.6 sının bekar, \%29.4 nün ise evli olduğu verilen beyanlardan anlaşılmaktadır.

Anket kapsamında sorulan sorulara ilişkin veriler değerlendirildiğinde "Mezun olduğunuz bölümü okumanız iş bulmanızı kolaylaştırdı mı?" sorusuna "hayır" diyenlerin oranı, \%83.3, "çalışma durumunuz nedir" sorusuna \%45.1 ile "alan dişında çalışıyor", \%34.3 ile "çalışmıyor" şeklinde beyan etmişlerdir. Mezunların çalıştıkları işyerinde belirtmiş oldukları aylık ücretlerin en yüksek olanı \%31.4 ile "ücreti belirtmeyenler" ilk sirada, ardından \%23.5 oranı ile "ailesi ile beraber çalışanlar", olarak beyanda bulunmuşlardır. Bunu 1300-2599 ₹ ile “düzensiz gelir" takip etmektedir. "Okulu bitirdikten sonra hedef ve beklentileriniz değiști mi?" sorusuna \%73.5 ile "hayır" diyenler, \%16.7 ile "kısmen" diyenler takip etmektedir. Bununla birlikte "aldığınız eğitim mesleği sevmenizi sağladı mı?” sorusuna öğrencilerin \%53.9'u “evet, \%20.6's1 “hayır” ve \%25.5'i ise "k1smen” şeklinde beyan etmişlerdir.

"Türkiye şartlarına göre yaşam standardınızı nasıl tanımlarsınız?" sorusuna öğrencilerin \%29.4'ü “çok düşük”, \%31.4'ü “düşük”, \%35.3'ü “orta” ve sadece \%3.9'u "yüksek” bir yaşam standardına sahip olduklarını bildirmişlerdir. "Mezun olduğunuz ilk dönemlerde ayrıldığınız işlerden neden ayrıldınız?" sorusuna en fazla \%37.3 ile "hiç çalışmadım" şeklinde beyan edenlerden sonra sıra ile "sektör dişında çalışıyordum" ve "aldığım ücret yeterli olmadığından" dolayı girdikleri işlerden ayrıldıklarını beyan etmişlerdir. "Mezun olduktan sonra ne kadar sürede iş buldunuz" sorusuna öğrencilerin salt çoğunluğu \%45.1 ile "halen çalışmıyorum" şeklinde beyan etmişlerdir. "Okuduğunuz programı çevrenize tavsiye eder misiniz?” sorusuna öğrencilerin $\% 58.8$ 'i “evet”, \%41.2'si ise "hayır" şeklinde tercihte bulunmuşlardır.

\section{Uyum Analizi sonuçlarına göre bulguların değerlendirilmesi}

Uyum analizi (Correspondance Analysis) genellikle iki ya da daha çok değişkenli çapraz tablolarda her bir değişkenin kategorileri arasındaki ilişkileri grafiksel olarak incelemektedir (Özdemir, 1999). Öğrencilerin mezun olduğu bölüm ile çalışma durumunu arasındaki ilişki Şekil 4'te verilmiştir. Buna göre Organik Tarım, Tarla Tarımı ve Bahçe Ziraatı Programlarından mezun öğrencilerin çalışma durumları benzerlik göstermiş olup çoğunlukla alan dışında çalıştıkları saptanmıştır. Tarla Tarımı programı mezunu öğrencilerinin diğer bir kısmının çalışma durumlarını "Çalışmıyor", Laborant ve Veteriner Programı mezunlarının ise çalışma durumlarını "Okuyor" olarak bildirdikleri görülmektedir. Hayvansal Üretim Programı'ndan mezunların çalışma durumu tercihlerinin ise "Alanında çalışıyor” olduğu eğiliminde olduğu gözlenmektedir. Ayrıca Ki-Kare testi sonucuna göre 
“Öğrencilerin Mezun Olduğu Program” ile "Çalışma Durumları” arasındaki ilişki istatistiksel olarak önemli bulunmuştur $(\mathrm{p}<0.01)$.

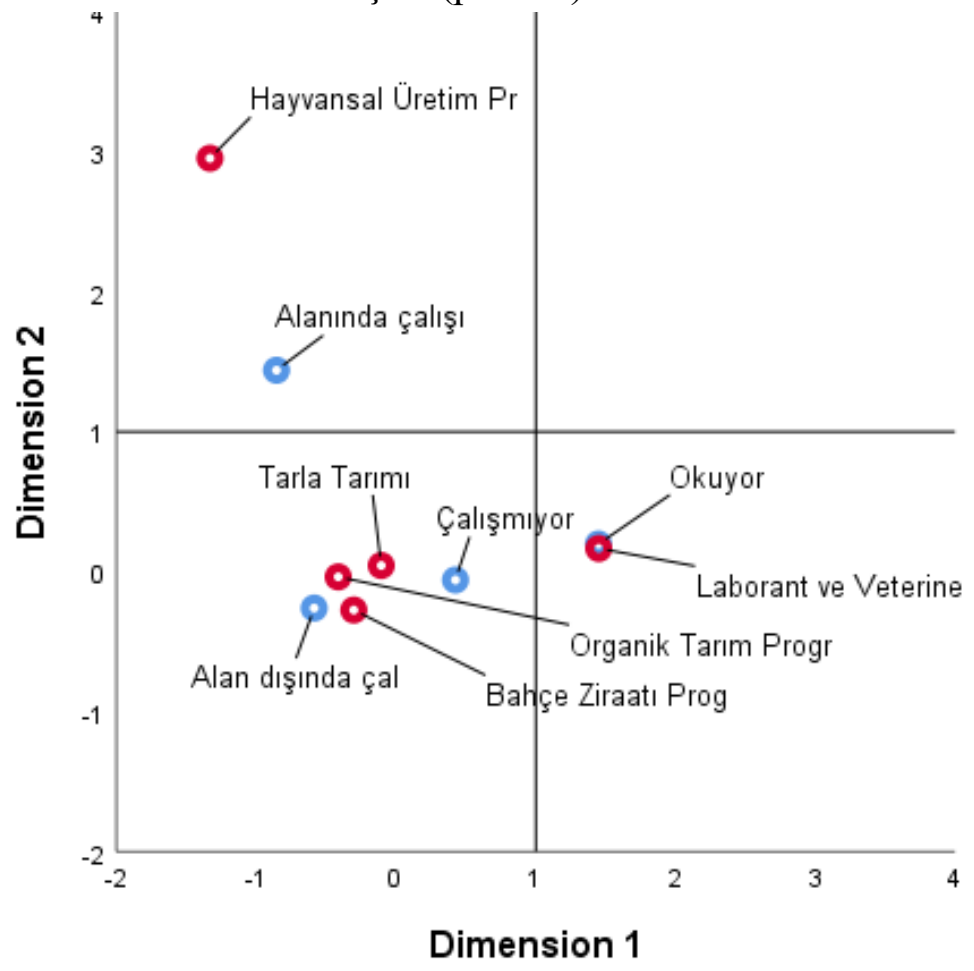

Şekil 4. Öğrencinin mezun olduğu bölüm ile çalışma durumu arasındaki uyum analizi.

Figure 4. Correspondance analysis between the department from which the student graduated and his/her employment status.

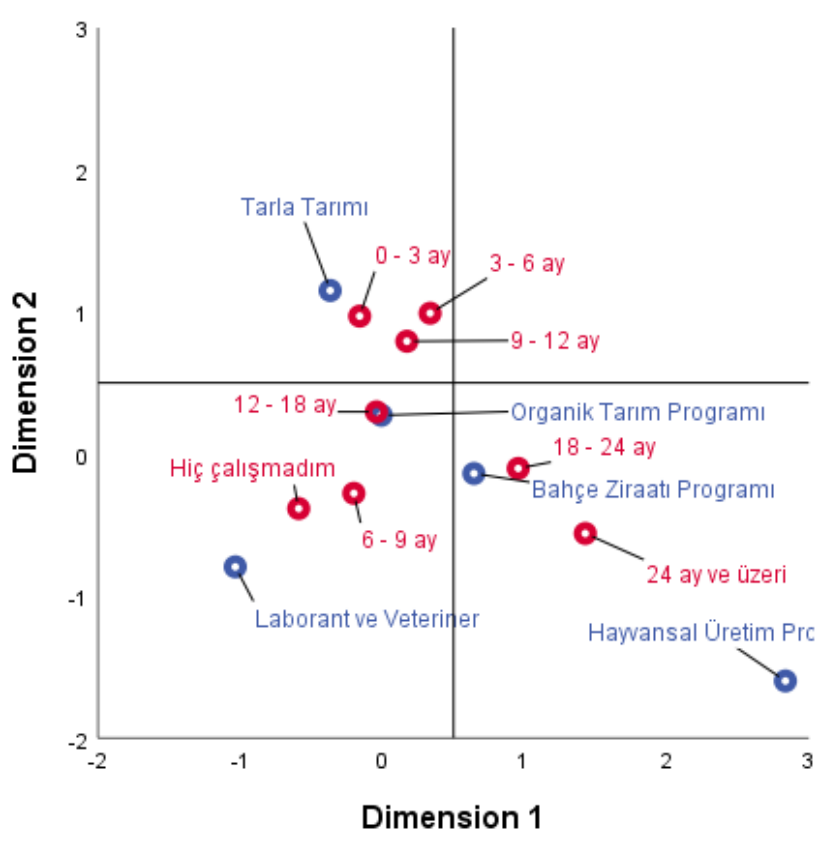

Şekil 5. Öğrencinin mezun olduğu bölüm ile mezun olduktan sonra ilk girdikleri işlerde ortalama ne kadar süre ile çalıştıkları arasındaki uyum analizi.

Figure 5. Correspondance analysis between the department from which the student graduated and "how long work on average in their first job" after graduation. 
Şekil 5'e göre Tarla Tarımı programından mezun olan öğrencilerin büyük bir kısmının ilk girdikleri işlerde 0-3 ay, diğer bir kısmının 3-6 ay ve 9-12 ay kadar çalıştıkları bildirilmiştir. Organik Tarım programından mezunların 12-18 ay çalıştıkları, fakat 0-3, 3-6, 69 ve 9-12 ay kadar süre ile çalıştıkları da görülmektedir. Bahçe Ziraatı programından mezunların daha çok 18-24 ay ve diğer mezunların ise 6-9, 12-18, 24 ay üzeri süre ile çalıştıkları eğiliminde oldukları gözlenmektedir. Hayvansal Üretim programından mezunların 24 ay ve üzeri bir süre ile çalıştıkları, Laborant ve Veteriner programından mezunların 'hiç çalışmadım' seçeneğini işaretledikleri görülmektedir. Öğrencilerin mezun oldukları program ile ilk girdikleri işte ne kadar süreyle çalıştıkları Ki-Kare testine göre aralarındaki ilişki istatistiksel olarak önemli bulunmuştur $(\mathrm{p}<0.01)$.

Mezunların işe başlamalarının ilk dönemlerinde ayrıldıkları işlerden neden ayrıldıkları ile mezun olunan program arasındaki ilişki Şekil 6'da verilmiştir. İki değişken arasındaki ilişki Ki-Kare testi sonucuna göre istatistiksel olarak önemli bulunmuştur $(\mathrm{p}<0.01)$. Buna göre Organik Tarım ile Bahçe Ziraatı programından mezunların işten ayrılma tercih nedenlerinin benzerlik gösterdiği ve daha çok "Kariyer imkanı daha iyi olan bir işe girmek için" ile "Aldığım ücret yeterli olmadığından" şeklindedir. Bunun yanısıra aynı grupta "Sektör dışında çalışıyordum" ile "Yöneticilerim ve çalışma arkadaşlarım tarafından rahatsız edildiğim için" işten ayrılma nedeni belirten mezun öğrenci de bulunmaktadır. Laborant ve Veteriner programından mezunların ise ifadelerinin hiç çalışmadıkları yönünde olduğu görülmektedir. Hayvansal Üretim programından mezunların net olmamakla beraber tercihlerinin “Ayrılmadım, halen aynı işte çalışıyorum” yönünde oldukları gözlenmektedir.
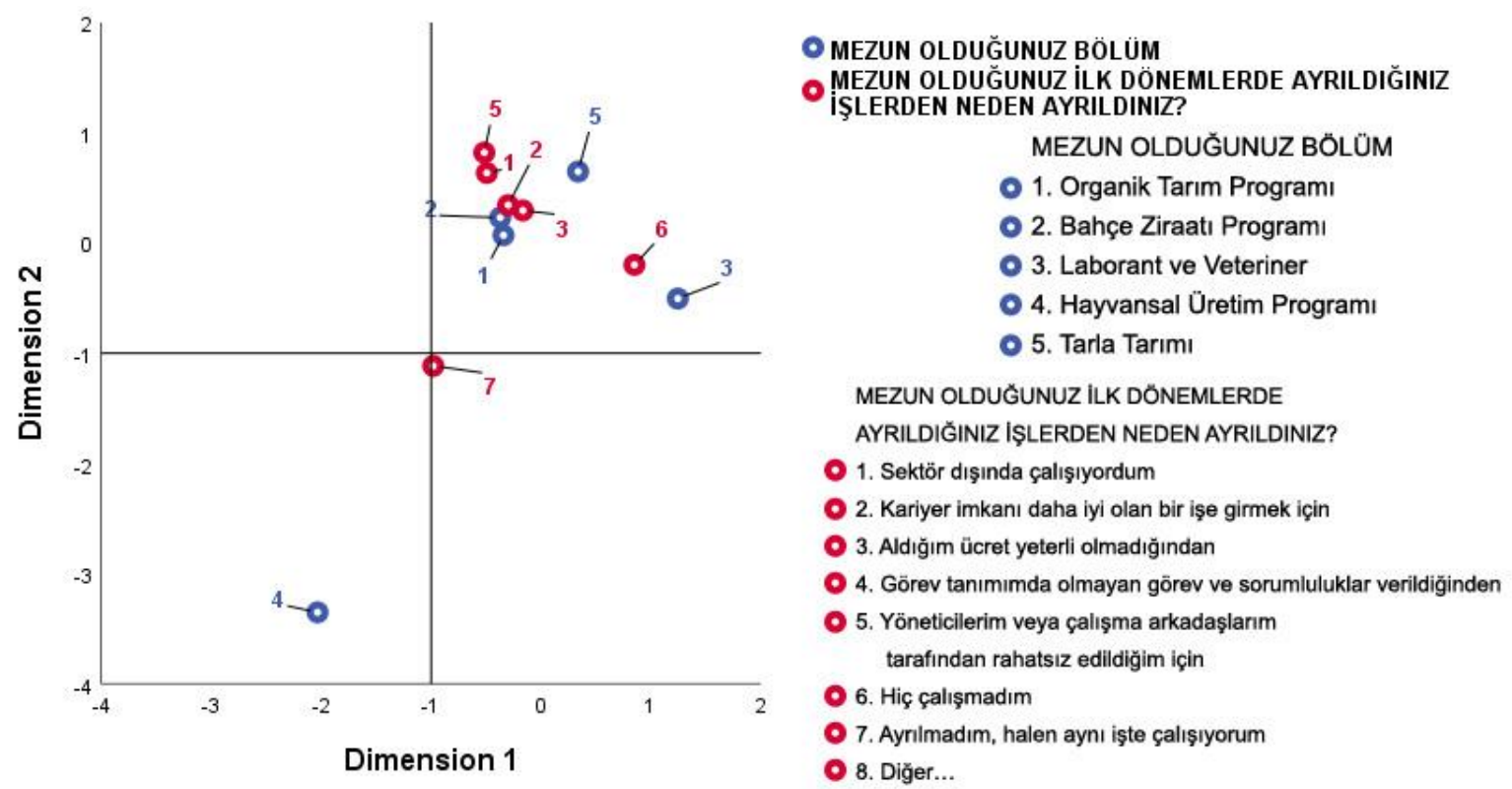

Şekil 6. Öğrencinin mezun olduğu bölüm ile mezun oldukları ilk dönemlerde ayrıldıkları işlerden neden ayrıldıkları arasındaki uyum analizi.

Figure 6. Correspondance analysis between the department from which the student graduated and "why they left their first job". 


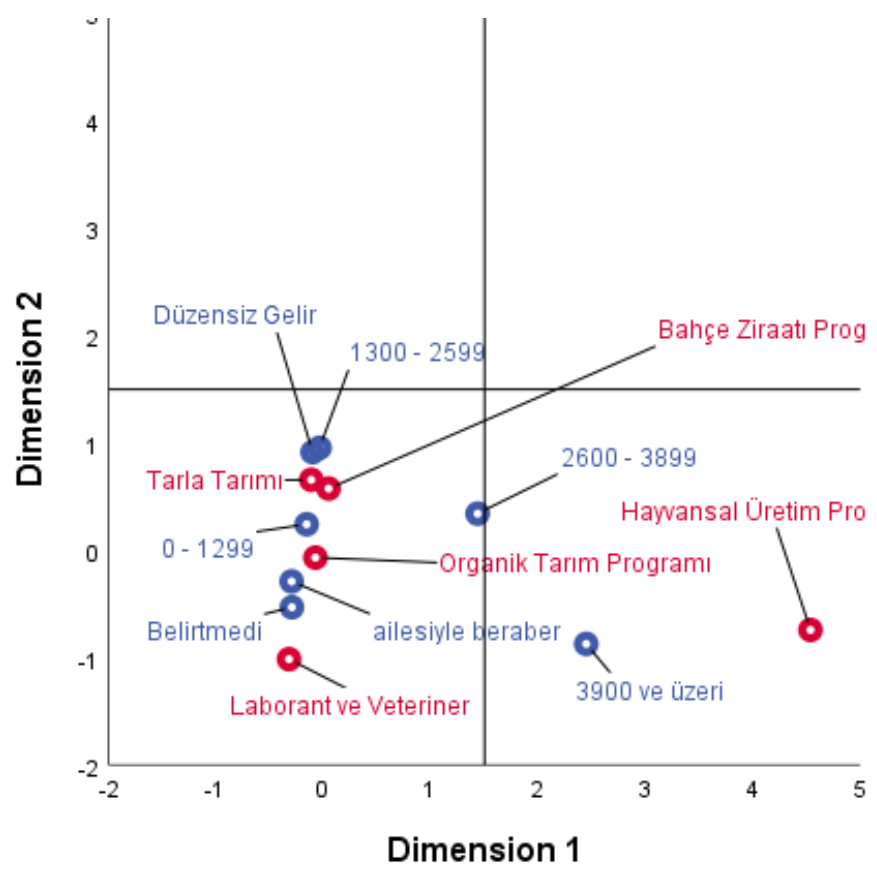

- MEZUN ÖĞRENCILERIN AYLIK ÜCRETLERI - MEZUN OLDUĞUNUZ BÖLÜM

Şekil 7. Öğrencilerin mezun olduğu bölüm ile aylık ücretleri arasındaki uyum analizi.

Figure 7. Compatibility analysis between the department from which the students graduated and their monthly fees.

Şekil 7 incelendiğinde, Bahçe Ziraatı ile Tarla Tarımı programlarından mezunların aylık ücretlerinin benzerlik gösterdiği ve düzensiz gelir, 1.300-2.599 € ve 0-1.299 £ şeklinde olduğu gözlenmektedir. Organik Tarım programı mezunlarının tercihlerinin çoğunlukla 01.299 €, ailesiyle birlikte ve belirtmekten çekindiği yönündedir. Laborant ve Veteriner programı mezunlarının tercihlerini belirtmediği tespit edilmiştir. Hayvansal Üretim programı mezunlarının ise net olmamakla birlikte 3.900 € ve üzeri aylık ücret aldıklarını bildirdikleri gözlenmektedir. Öğrencilerin mezun oldukları program ile aylık ücretleri arasındaki ilişki istatistiksel olarak önemli bulunmuştur $(p<0.01)$

"Okulu bitirdikten sonraki hedef ve beklentilerim değişmedi" tercihinde bulunanların çoğunluğunu 25-28 ile 29-32 yaş grubundaki mezunlar oluşturmaktadır (Şekil 8). 21-24 yaş aralığındakilerin de büyük bir kısmı "beklentim değişmedi" yönünde tercihte bulunmuşlardır. "Kısmen değişti" diyenler daha çok 37 yaş ve üzeri mezunların olduğu yönündedir. "Evet beklenti ve hedeflerim değişti" diyenler ise daha çok 17-20 ile 33-36 yaş grubundaki mezunların olduğu gözlenmektedir. Ki- Kare testi sonucuna göre mezunların yaşları ile beklenti ve hedeflerinin gerçekleşmesi arasındaki ilişki istatistiksel olarak önemli bulunmuştur $(\mathrm{p}<0.01)$. 


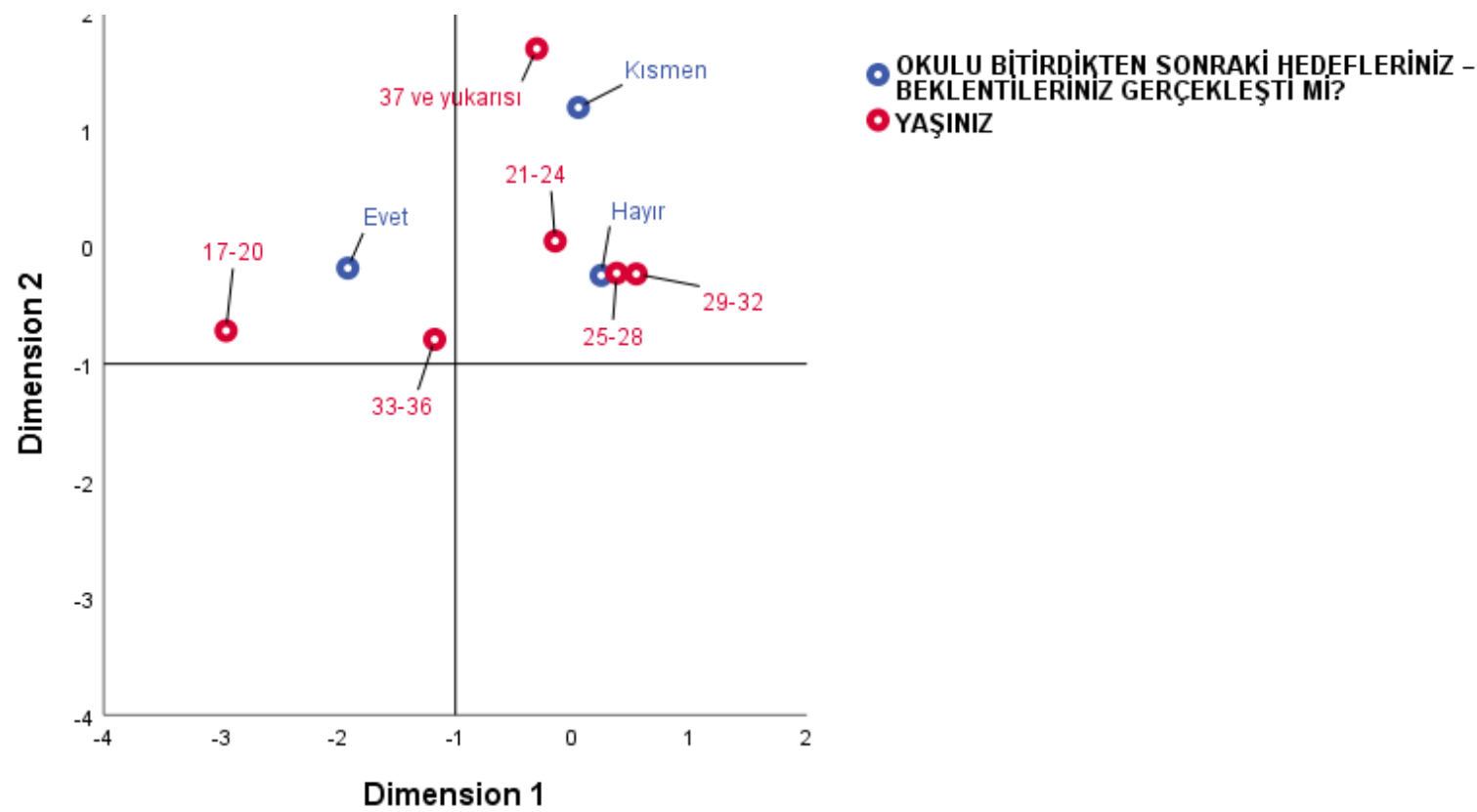

Şekil 8. Mezunların yaşı ile okulu bitirdikten sonraki hedef ve beklentilerinin gerçekleşme durumu arasindaki uyum analizi.

Figure 8. Correspondance analysis between the age of the graduate student and the "realization of the goals and expectations after graduation".

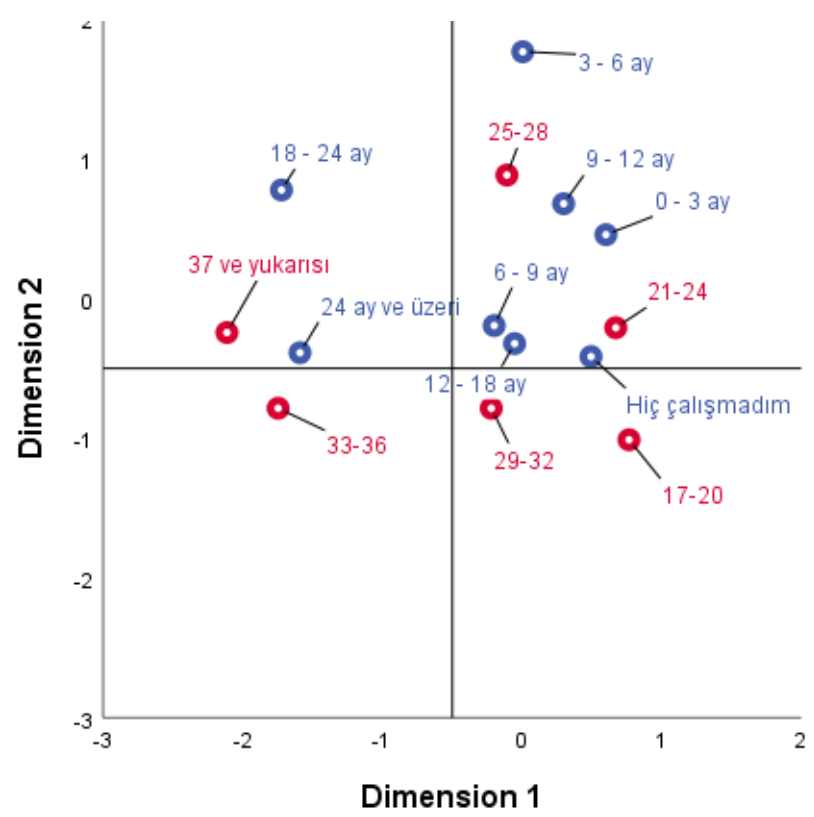
MEZUN OLDUKTAN SONRA ILK GIRDiĞiNiz işLERDE
ORTALAMA NE KADAR SÜREYLE ÇALIŞTINIŽ? - YAŞINIZ

Şekil 9. Mezunların yaşı ile mezun olduktan sonra ilk girdiği işlerde ortalama ne kadar süre çalıştıkları arasındaki uyum analizi.

Figure 9. Correspondance analysis between the age of the graduated student and "how long they worked on average in their first job" after graduation.

Mezunların yaşları ile mezun olduktan sonra ilk girdikleri işlerde ortalama ne kadar süre çalıştıkları ile ilgili uyum analizi Şekil 9'da verilmiştir. Buna göre 17-20 yaş grubundakiler ile 21-24 yaş grubundakilerin beyanlarının hiç çalışmadıkları yönünde, 29-32 
yaş grubundakilerin daha çok 12-18 ay ve bir kısmınında 6-9 ay kadar çalıştıklarını beyan etmişlerdir. Bununla birlikte yaş ilerledikçe (33-36 ile 37 ve yukarısı yaştakiler) ilk girdikleri işlerde daha uzun süre çalıştıkları (24 ay ve üzeri) gözlenmektedir. 25-28 yaş aralığındaki mezunların ise kararsız bir durum sergiledikleri anlaşılmaktadır. $\mathrm{Bu}$ yaş grubundakilerin çoğunluğunu 9-12 ay ve diğer kalanların ise 0-3 ile 3-6 ay arasında çalıştıkları görülmektedir. Mezunların yaşları ile mezun olduktan sonra ilk girdikleri işlerdeki çalışma süreleri arasındaki ilişki Ki-Kare testine göre istatistiksel olarak önemli bulunmuştur $(\mathrm{p}<0.01)$.

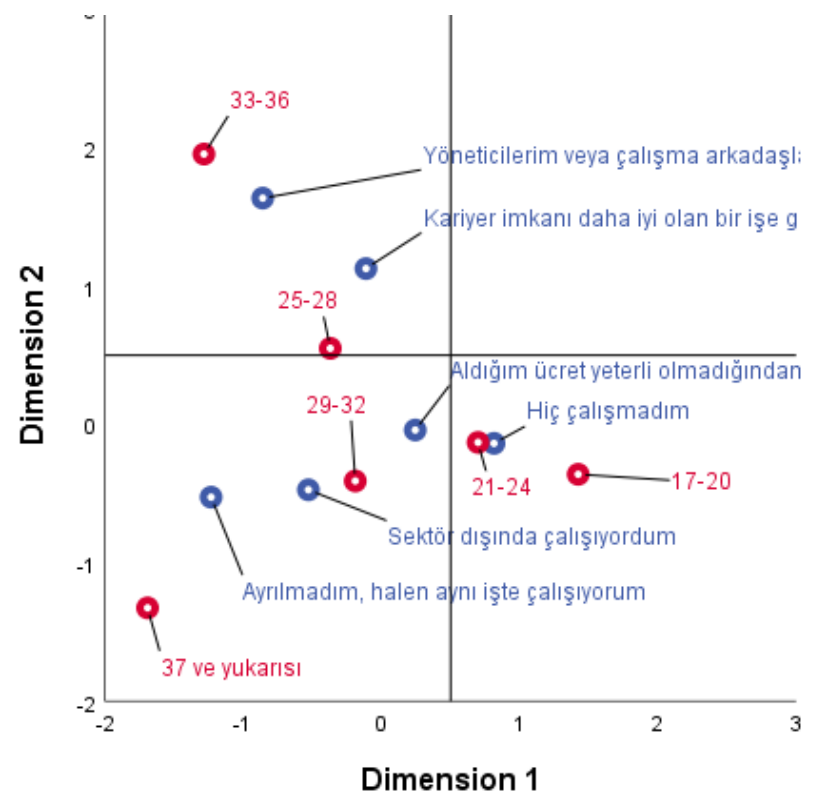

- MEZUN OLDUĞUNUZ ILKK DÖNEMLERDE AYRILDIĞINIZ O YAŞINIZ

Şekil 10. Mezunların yaşı ile mezun olduktan sonraki ilk dönemlerde ayrıldıkları işten neden ayrıldıkları arasındaki uyum analizi.

Figure 10. Correspondance analysis between the age of the graduate student and "why he left his first job" after graduation.

Mezunların ilk dönemlerdeki işlerinden ayrılma nedenleri ile yaşları arasındaki ilişki Ki-Kare testine göre anlamlı bulunmuştur (Şekil 10) $(\mathrm{p}<0.01)$. Şekil 10 incelendiğinde 37 yaş ve üzeri gruptakilerin işten ayrılmadıkları ve halen çalıştıkları eğiliminde oldukları, 29-32 yaş grubundakilerin büyük bir kısmı sektör dışında çalıştıkları ve bir kısmı da aldığ1 ücretin yeterli olmamasından dolayı işlerden ayrıldıklarını dile getirmişlerdir. 21-24 ile 17-20 yaş aralığındaki mezunların çalışmadıkları yönünde durum beyan etmişlerdir. 25-28 yaş grubundakilerin "Kariyer imkanı daha iyi bir yere geçmek" istemeleri ile "Yöneticilerim veya çalışma arkadaşlarım tarafından rahatsız edildiğim için" işi bıraktım seçeneğini seçtikleri gözlenmektedir. "Yöneticilerim veya çalışma arkadaşlarım tarafindan rahatsız edildiğim için" seçeneğini 33-36 yaş grundaki mezunların bir kısmınında seçtiği görülmektedir.

Şekil 11 incelendiğinde mezunların yaşı ile iş bulma süresi arasındaki ilişki araştırılmış ve elde edilen bulguların uyum analizi aşağıda verilmeye çalışılmıştır. Buna göre 17-20 yaş grubu, 21-24 ve 29-32 yaş grubu mezunlarının büyük bir çoğunluğunun koşulları benzerlik gösterdiği ve "Halen çalışmıyorum" ile "Ailem ile birlikteyim iş aramıorum" yönünde bir durumda oldukları bildirilmiştir. Yine 29-32 yaş grubunun diğer bir kısmının ise 3-6, 0-3 ay gibi bir sürede iş buldukları gözlenmiştir. 25-28 yaş grubu öğrencilerin çoğunun 0- 
3 ve 3-6 ay gibi sürelerde iş buldukları tespit edilmiştir. 37 ve yukarısı grubun çoğunluğunu 12 ay ve üzeri, diğer kısmın ise 3-6 ay arasındaki bir sürede iş buldukları anlaşılmıştır. 33-36 yaş grubu mezunların ise 6-9, 9-12 ve 0-3 ay gibi sürelerde iş buldukları bildirilmiştir. Yaş ve iş bulma süresi arasındaki ilişki istatistiksel olarak önemli bulunmuştur $(\mathrm{p}<0.05)$.

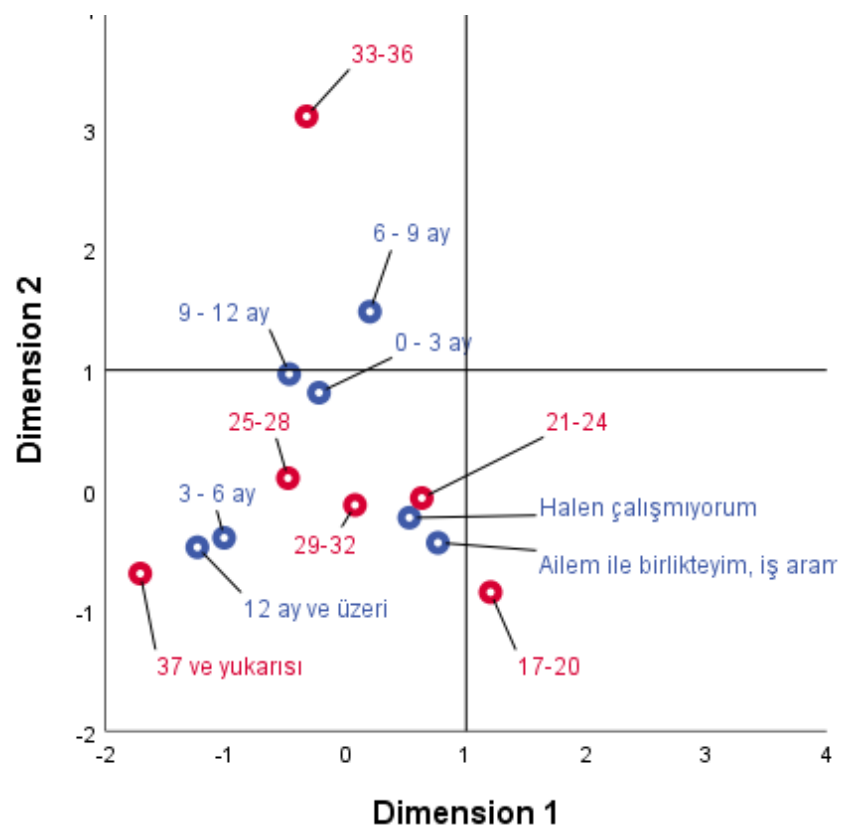

- MEZUN OLDUKTAN SONRA NE KADAR SÜREDE iş

- YAŞINIZ

Şekil 11. Mezunların yaşı ile mezun olduktan sonra ne kadar sürede iş buldukları arasındaki uyum analizi.

Figure 11. Correspondance analysis between the age of the graduated student and "how long it takes to find a job after graduation".

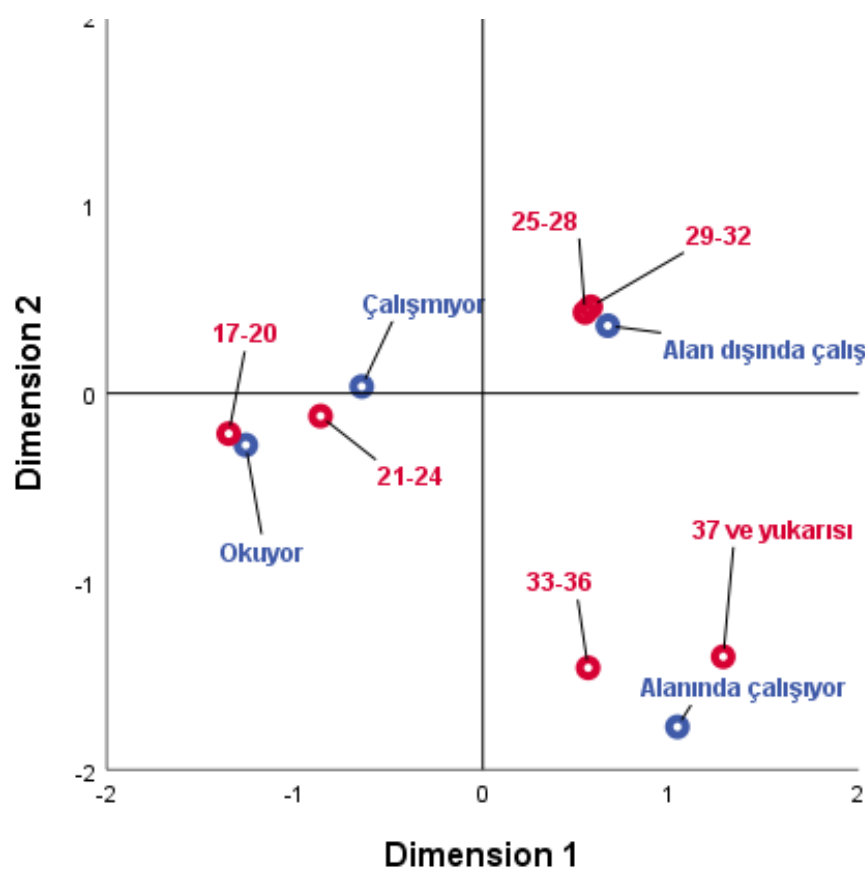

- çalıŞMA DURUMUNUZ

- YAŞINIZ

Şekil 12. Mezunların yaşı ile çalışma durumu arasındaki uyum analizi.

Figure 12. Correspondance analysis between graduated student's age and employment status. 
Mezunların yaşları ile çalışma durumları arasındaki uyum analizi Şekil 12'de veilmiştir. Buna göre 25-28 ile 29-32 yaş grubundaki öğrencilerin alan dişında çalıştıkları, 3336 yaş grubu ile 37 ve yukarısı yaş grubunun ise kendi alanlarında çalıştıkları görülmektedir. Bunun yanısıra 17-20 yaş grubunun eğitime devam ettikleri, 21-24 yaş grubundakilerin bir kısmının çalışmadığı, bir kısmının ise eğitime devam ettikleri gözlenmiştir. Mezunların yaşları ile çalışma durumları arasındaki ilişki Ki-Kare testine göre istatistiksek olarak önemli bulunmuştur $(\mathrm{p}<0.01)$

Çalışmada bir başka çarpıcı nokta ise öğrencilerin mezun oldukları yıl grubu ile ilk girdikleri işlerde ne kadar süreyle çalıştıkları arasındaki ilişkinin (Şekil 13) istatistiksek olarak önemli olmasıdır ( $\mathrm{p}<0.05)$. Buna göre 2017-2019 yılı mezunlarının büyük bir kısmının hiç çalışmadıkları, geri kalanların 0-3, 3-6, 6-9, 12-18 ay gibi sürelerle çalıştıkları bildirilmiştir. 2005-2007 yılı mezunlarının ise 18-24 ile 24 ay ve üzeri süre ile çalıştıkları görülmektedir. 2011-2013 ile 2014-2016 yılı mezunlarının ise daha çok 0-3 ay ile 9-12 ay kadar çalıştıkları gözlenmektedir. 2008-2010 mezunlarının çoğunluğu ilk girdikleri işte 3-6 ay kadar süre ile çalıştıkları anlaşılmıştır.

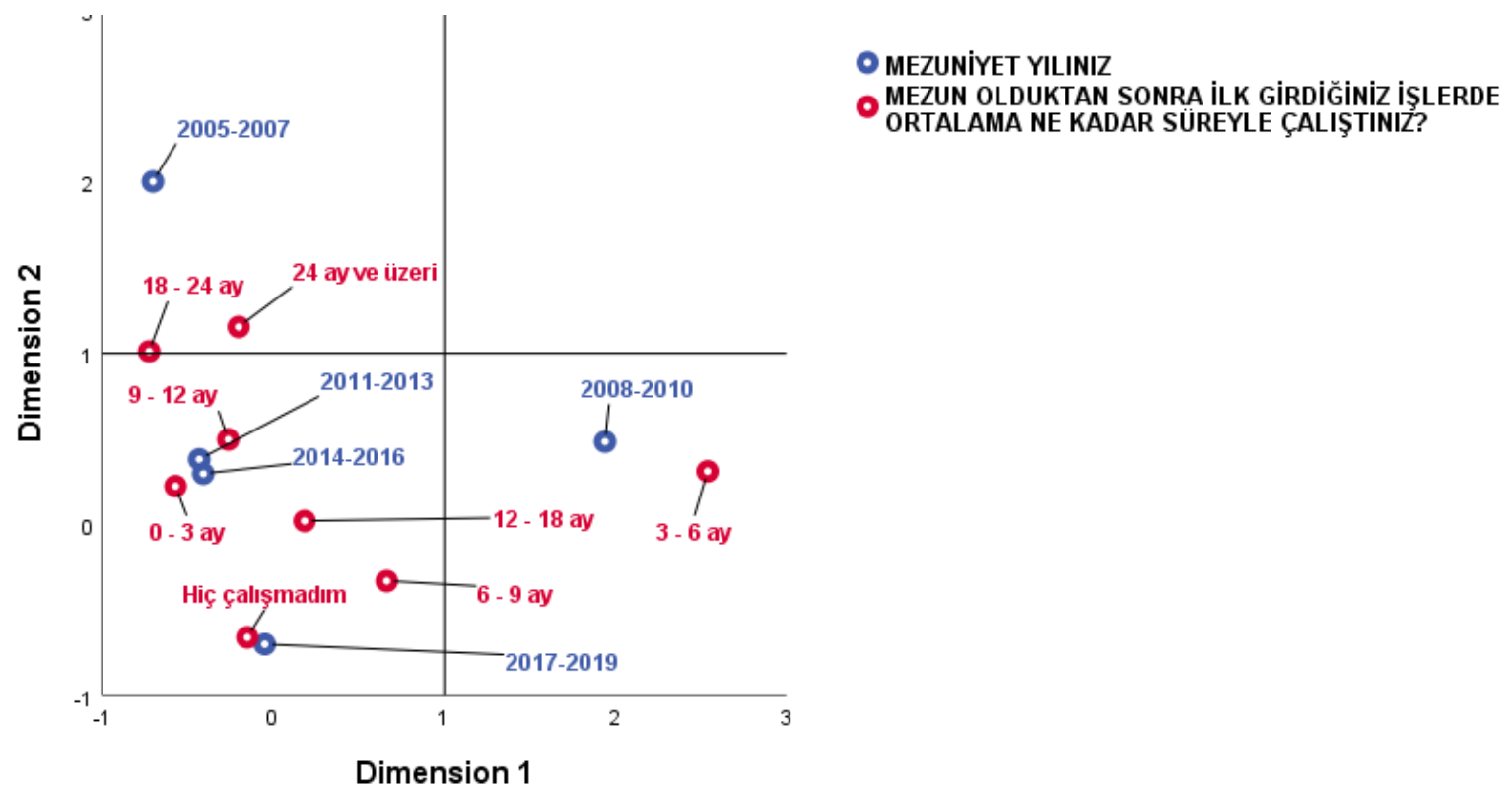

Şekil 13. Mezuniyet yılı yıl ile mezun olduktan sonra "İlk işlerinde ortalama ne kadar süre ile çalıştıkları" arasındaki uyum analizi.

Figure 13. Correspondance analysis between the year of graduation and "how long on average they worked in their first job" after graduation.

Şekil 14 incelendiğinde, 2005-2007 yılları grubuna dahil Mezunların durumlarını "Ayrılmadım, halen aynı işte çalışıyorum" şeklinde beyan ettikleri, 2014-2016 yılı grubundakilerin büyük bir kısmı "Aldığım ücret yeterli olmadığından" ve diğer bir kısmının "Kariyer imkanı daha iyi olan bir işe girmek" ve "Sektör dışında çalışıyordum" nedenlerinden dolayı işten ayrıldıklarını bildirmişlerdir. 2017-2019 yılı grubundaki mezunların çoğu ise "Hiç çalışmadım" şeklinde beyanda bulundukları, diğer bir kısmının ise "kariyer imkanı daha iyi olan bir işe girmek", "Sektör dışında çalışıyordum" ve "Aldığım ücret yeterli olmadığından" nedenleri ile işten ayrıldıklarını belirtmişlerdir. 2011-2013 yılı grubundaki mezunların büyük bir çoğunluğu durumlarını "Sektör dışında çalışıyordum" (kendi alanı dışındaki) şeklinde 
ifade etmişlerdir. 2008-2010 mezunları ise durumlarını "Yöneticilerim veya çalışma arkadaşlarım tarafından rahatsız edildiğim için” işten ayrıldım şeklinde beyanda bulunmuşlardır.

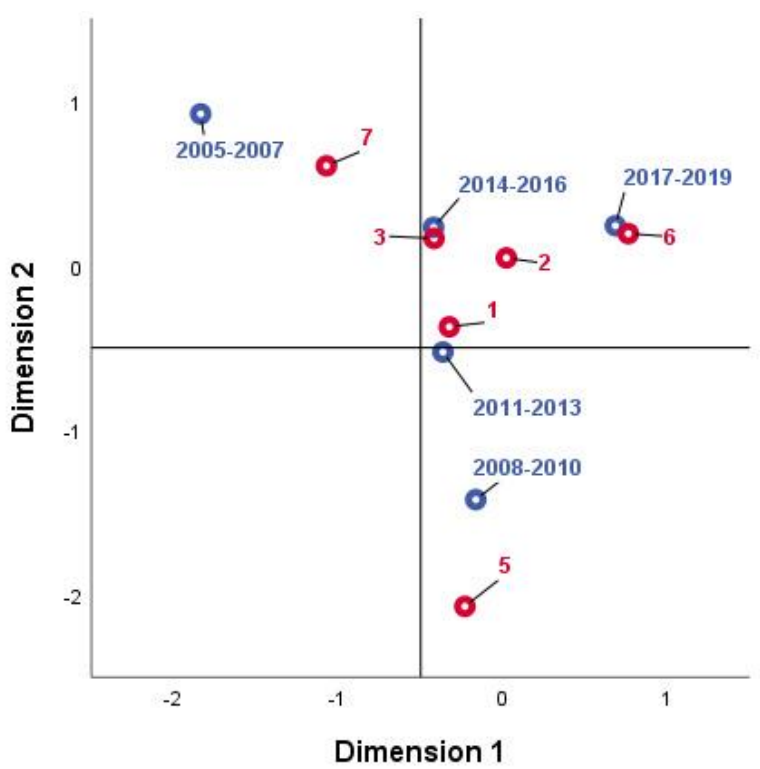
- MEZUNIYET YILINIZ
MEZUN OLDUĞUNUZ ILK DÖNEMLERDE AYRILDIĞINIZ
IŞLERDEN NEDEN AYRILDINIZ?

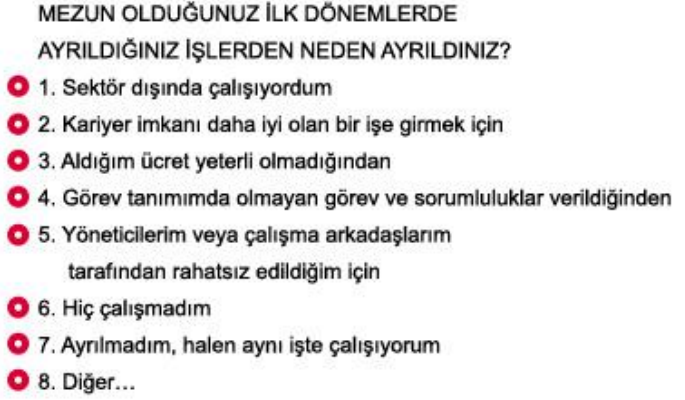

Şekil 14. Mezuniyet yılı ile mezun olduktan sonra ilk dönemlerde ayrıldığg işlerden ayrılma nedenleri arasındaki uyum analizi.

Figure 14. Correspondance analysis between graduation year and "reasons for leaving the first job" after graduation.

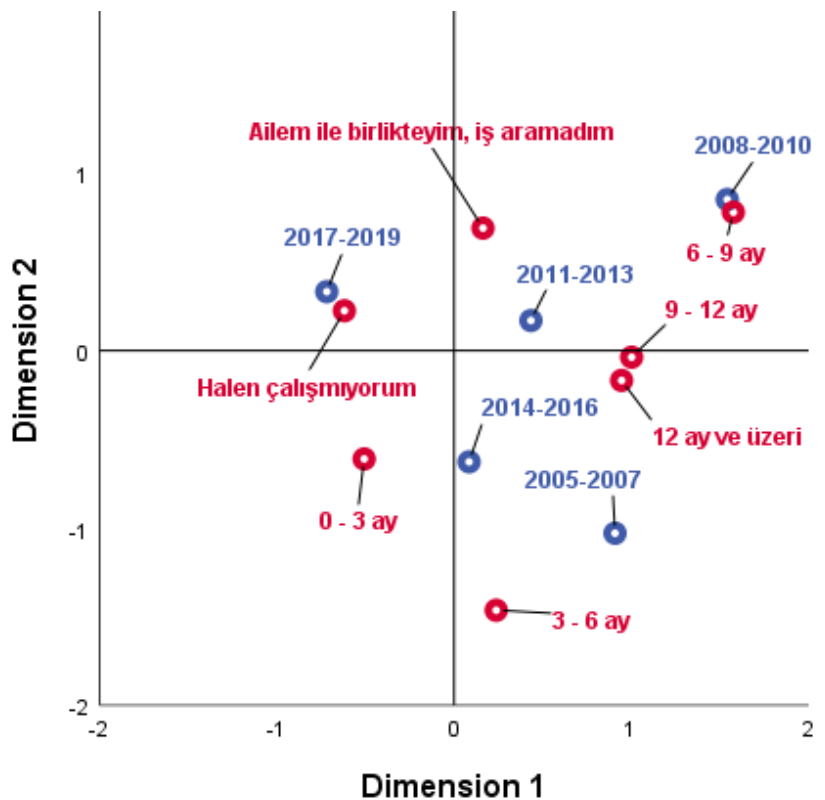

- MEZUNIYET YILINIZ

MEZUN OLDUKTAN SONRA NE KADAR SÜREDE iş BULDUNUZ

Şekil 15. Mezuniyet yılı ile mezun olduktan sonra ne kadar sürede iş buldukları arasındaki uyum analizi

Figure 15. Correspondance analysis between graduation year and "how long it takes to find a job" after graduation. 
Önemli olabilir düşüncesi ile öğrencilerin mezuniyet yılı grubuna göre öğrencinin ne kadar sürede iş buldukları arasındaki ilişkinin Ki-Kare testi ile uyum analizine de bakıldı, ilgili grafik Şekil 15 te verilmiştir. Buna göre en kısa süre içerisinde (0-3 ay) iş bulan grubun 2014-2016 yılları arasında mezun grubun olduğu gözlenmektedir. 2017-2019 y1l mezunlarının çoğunlukla halen çalışmadığı, 0-3 ay ile "Ailem ile birlikteyim, iş aramadım" diyenlerin olduğu görülmektedir. 2005-2007 yılı grubu mezunlarının beyanı ise 3-6, 9-12 ile 12 ay ve üzeri sürede iş buldukları yönündedir. 2011-2013 yılı grubundakilerin çoğu 9-12 olmakla birlikte "12 ay ve üzeri" ile "Ailem ile birlikteyim, iş aramadım" şeklinde beyanda bulunmuşlardır. 2008-2010 yılı mezun grubu öğrenci beyanlarının çoğunluğunu 6-9 ay, 9-12 ile 12 ay ve üzeri beyanda bulunanlar da mezunların diğer bir kısmını oluşturmaktadır. Mezuniyet yılı ile öğrencilerin ne kadar sürede iş buldukları arasında yapılan Ki-Kare testine göre aralarındaki ilişki istatistiksel olarak önemli bulunmuştur $(\mathrm{p}<0.01)$.

\section{Sonuç ve Öneriler}

\section{Mezun olunan program bakımından;}

Bulgular değerlendirildiğinde Organik Tarım, Tarla Tarımı ve Bahçe Ziraatı Programı mezunlarının çoğunlukla "alan dişında" kısa sürelerde çalışııkları ve buralardan da çeşitli nedenlerle ayrıldıkları, çalıştıkları süre içerisinde de aylık ücretlerinin çok düşük olduğu belirlenmiştir. Hayvansal Üretim Programı mezunları çoğunlukla kendi alanlarında ve diğer program mezunlarından çok daha uzun süreyle çalıştıklarını ve çalıştıkları sürelerde diğer program mezunlarından daha yüksek ücret aldıklarını, Laborant ve Veteriner programı mezunları ise çoğunluğu eğitimlerine devam ettiklerini, herhangi bir işte çalışmadıklarını beyan etmişlerdir.

\section{Ö̆̆rencinin yaşı bakımından;}

17-20 yaş grubu mezunlar, mezun olduktan sonra, hedef ve beklentilerinin değiştiğini ve hiç çalışmadıklarını beyan ederken 21-24 yaş grubu mezunların hedef ve beklentilerinin değişmediğini, herhangi bir işte çalışmadıklarını, çok az bir kısmının da eğitimlerine devam ettiklerini bildirmiş̧lerdir. 25-28 yaş grubu mezunların hedef ve beklentileri değişmemiş, çok farklı sürelerde iş bulduklarını fakat girdikleri işlerde en fazla 12 ay çalıştıklarını, çoğunlukla kariyer imkânı daha iyi bir yere geçmek veya işyerinde rahatsı edildikleri için işten ayrıldıklarını belirtmişlerdir. 29-32 yaş grubu mezunların da hedef ve beklentileri değişmemiş, çoğunluğu çalışmamakla beraber ilk girdikleri işlerde en fazla 12-18 ay çalıştıklarını, çalıştıkları işlerden de sektör dışında ve yetersiz ücretle çalışmış olmalarından dolayı ayrıldıklarını beyan etmişlerdir. 33-36 yaş grubu mezunları farklı olarak mezun olduktan sonra hedef ve beklentilerinin değiştiğini, ilk 12 ay içerisinde kendi alanlarında iş bulduklarını ve ilk girdikleri işlerde diğer yaş gruplarından çok daha uzun süre ile (24 ay ve üzeri) çalıştıklarını vurgulamışlardır. İşten ayrılma sebebi olarak yöneticileri ve iş arkadaşları tarafindan rahatsız edilmelerini göstermişlerdir. 37 yaş ve üzeri mezunlar da hedef ve beklentilerinin kısmen değiştiğini, çoğunlukla 12 ay ve üzeri sürelerde kendi alanlarında iş bulduklarını ve halen çalışıklarını ifade etmişlerdir. 


\section{Mezuniyet yılları bakımından;}

2005-2007 mezunları çoğunlukla ilk 12 ayda iş bulduklarını, daha sonraki yıllarda mezun olanlardan daha uzun süre ile çalıştıklarını ve halen çalıştıklarını bildirmişlerdir. 20082010 mezunları ilk 6-12 ay içerisinde iş bulduklarını, çoğunlukla ilk girdikleri işlerde 3-6 ay gibi kısa süreler çalıştıklarını, işten ayrılma sebebi olarak da yönetici ve iş arkadaşları tarafindan rahatsız edilmelerini öne sürmüşlerdir. 2011-2013 mezunları çoğunlukla 9-12 ay içerisinde iş bulduklarını ve 0-3 ay veya 9-12 ay çalıştıklarını, çoğunlukla sektör dışında çalıştıklarından dolayı işten ayrıldıklarını beyan etmişlerdir. 2014-2016 mezunları diğer mezunlara göre 0-3 ay gibi çok kısa bir sürede iş bulmuşlar ve bu işlerde 0-3 ay ile 9-12 ay gibi sürelerde çalışmışlardır. Aldıkları ücretin yetersizliği, kariyer yapma imkânının daha iyi olduğu bir iş bulmak veya sektör dışında çalışıyor olmak gibi nedenlerle işten ayrıldıklarını bildirmişlerdir. 2017-2019 mezunlarının büyük bir kısmı hiç çalışmamış, çalışanlar 0-3 ay gibi bir sürede iş bulduklarını, bu işlerde en fazla 18 ay süreyle çalıştıklarını, "Kariyer imkanı daha iyi olan bir işe girmek", "Sektör dışında çalışıyor olmak" ve "Aldığım ücret yeterli değildi" gibi nedenler ile işten ayrıldıklarını belirtmişlerdir.

Elde edilen bu sonuçlar değerlendirildiğinde Gevaş ve Başkale Meslek Yüksekokulları Bitkisel ve Hayvansal Üretim Bölümleri’nden mezun olan öğrencilerin durumu, sektör talepleri, eğitim ve istihdam arasındaki ilişkinin hedeflere uygun bir şekilde devam etmediği anlaşılmaktadır. Bu durumun düzeltilmesine yönelik olarak, eğitim politikalarının yanısıra iş ve istihdam edilmeleri ile ilgili yasal düzenlemelerin yapılması gerekli gibi görülmektedir.

Bunlara ilave olarak ankete katılan öğrencilerin büyük bir çoğunluğu mesleklerini icra edemedikleri, daha çok alan dışında ve kısa süreli işlerde çalıştıkları aynı zamanda yaşamlarını almış oldukları mesleki eğitime göre şekillendiremedikleri anlaşılmaktadır. Mezunların \%20'ye yakın bir kısmı ise meslek yüksekokulunu bir basamak olarak görmekte ve okumaya devam ettikleri anlaşılmaktadır. Ayrıca gerçekleştirilen bu anket çalışmasına göre, öğrencilerin önemli düzeyde kararsızlık ve belirsizlik düşünceleri içinde olduğunu söylemek mümkündür. Bu konuda yükseköğretim kurumları ile ilgili sektörün iş birliğine dayalı özendirici ve istihdam yaratıcı tedbirler alınması gerekmektedir. Ayrıca mezun öğrencilere kendi mesleklerini yapacakları ve doğrudan üretime katkı verecekleri olanaklar (kredi vb. gibi) sağlanmak yerinde olacaktır.

\section{Teșekkür}

$\mathrm{Bu}$ araştırmaya FAP-2019-8536 numaralı proje kapsamında maddi destek sağlayan Van Yüzüncü Yıl Üniversitesi Bilimsel Araştırma Projeleri Koordinasyon Birimi'ne teşekkür ederim.

\section{Kaynaklar}

Atay, O., Gökdal, Ö., Helva, İ.B., Sarı, H.A., Yarali, E., Özuğur, A.K. 2016. Çine Meslek Yüksekokulu Mezunlarının Istihdam Edilme Durumlarının Değerlendirilmesi. UMYOS 2016, 5th International Vocational Schools Symposium, Prizren May 2016.

Çelikyürek, H., Gökdal, Ö., Balcı, H. 2017. Öğrencilerin Gevaş ve Başkale Meslek Yüksekokulları Bitkisel ve Hayvansal Üretim Bölümlerini Tercih Nedenlerinin 
Belirlenmesine İlişkin Bir Çalışma. Van YYÜ Tarım Bilimleri Dergisi, (YYU J Agr Sci), 27(4): 613-622.

İşseveroğlu, G., Gençoğlu, Ü.G. 2011 Türkiye'de Meslek Yüksekokullarının Bölge İhtiyaçlarına Uygunluğu Üzerine Bir Arastırma. Muhasebe ve Finansman Dergisi, (49), 24-36.

Kaya, A. 2014. Meslek Yüksekokulunda Öğrenim Gören Öğrencilerin Eğitim Öğretim ve Geleceğe Yönelik Düşünceleri. OMÜ Eğt. Fak. Derg. / OMU J. Fac. Educ. 2014, 33(2), 349-356 doi: 10.7822/omuefd.33.2.1.

Özdemir, P. 1999. Uygunluk analizi ve uygulaması. (Yüksek lisans tezi). YÖK Tez Merkezinden Erişilebilir. (Tez No. 080917).

Özuğur, A.K., Gökdal, Ö., Atay, O., Sarı, H.A. 2016. Çine Meslek Yüksekokulu Gıda ve Tarım Programları Son Sınınf Öğrencilerinin Mesleki Eğitim Algılarındaki Değişimlerin Değerlendirilmesi. Uluslararası Yükseköğretimde Meslek Eğitimi ve Öğretimi Sempozyumu. 12-15 Ekim Çorum/Türkiye.

SAS, 2020. SAS/Stat Software Hangen and Enhanced, SAS Institute Incorporation, USA.

Uçar, C., Özerbaş, MA. 2013. Meslewki ve teknik eğitimin dünyadaki ve Türkiyedeki konumu eğitim ve öğretim araştırmaları dergisi (journal of researc in education and teaching). Cilt:2 sayı :2, makale no: 28 ISSN:21. 